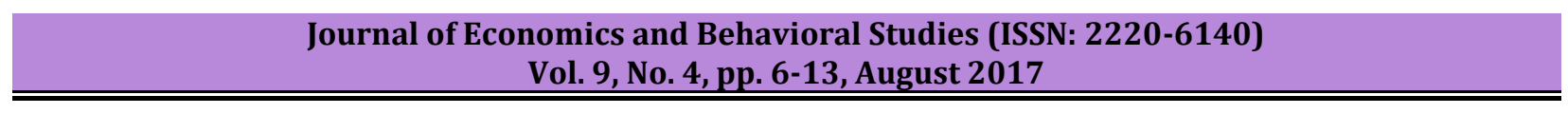

\title{
Unlocking the Potential of Women Entrepreneurs in the Tourism and Hospitality Industry in the Eastern Cape Province, South Africa
}

\author{
Vikelwa Judith Nomnga \\ Walter Sisulu University, South Africa \\ vnomnga@wsu.ac.za
}

\begin{abstract}
At the height of political turmoil and the so-called economic downgrade to 'junk' status by rating agencies in South Africa, the tourism and hospitality industry, through women entrepreneurship, seems to be an alternative exit the government can use to foster economic growth and curb unemployment. The paper adopts an extensive documentary review analysis to determine the challenges and opportunities for women entrepreneurs in the tourism industry in South Africa. The paper observes that women entrepreneurs in the Eastern Cape Province face a myriad of challenges emanating from low levels of education, lack of financial resources, poor information dissemination, gender inequity, limited support from stakeholders, limited technical skills and reluctance to shift from status quo. The paper concludes that, to unlock the potential of tourism and hospitality industry, women entrepreneurs need to embrace education and get trained on how to use modern technologies-which is fundamental in coping with the trends in the globalized environment. The paper recommends and empowers women to be at the forefront and become active entrepreneurs in tourism opportunities whereby stakeholder funding is the key to achieve economic growth.
\end{abstract}

Keywords: Women Entrepreneurs, Tourism, Hospitality Industry, Women Empowerment, Job Creation

\section{Introduction}

Throughout Sub-Saharan Africa, South Africa has been widely known as the hub of tourism and hospitality industry due to its vast tourist resort areas which saw the influx of world travelers in areas such as Cape Town's Table Mountain, Drakensberg Mountains in the Eastern Cape as well as other beautiful sites in seaside areas such as Durban, Port Elizabeth just to mention a few. At the epicenter of this huge tourism activity is women entrepreneurship which is fast gaining recognition although few studies in South Africa have documented it. IFAD (2005:5) asserts that, women entrepreneurship in the tourism and hospitality industry ignites economic growth in most developing countries and clearly represents an untapped potential. It is imperative to realize that for many women in rural areas, even in South Africa, women entrepreneurship facilitates a broader livelihood strategy often undertaken on a part-time basis, or usually where there is a difficulty in separating production and reproduction tasks as well as market and non-market work (ILO, 2001). Women entrepreneurs are useful in tapping the potential of tourism and hospitality industry hence their pivotal role in the social and economic well-being for communities in South Africa. Much more important is the fact that, women entrepreneurship (for example through cooperatives or clubs, bed and breakfast accommodations, lodges) activities have gained government recognition and the value of their contribution to their communities by giving them support and promoting a change in their attitudes towards the meaning of work (Women in Africa Doing Business, 2008). A significant number of South African women entrepreneurs contribute much to the rural economy although many still suffer from gender equity and lack of adequate finance to spearhead tourism activities. Despite these obstacles, many women entrepreneurs have forged an exit strategy into informal entrepreneurship in areas such as catering, fashion designing, cooking and being wedding coordinators (White, Jones, Riley \& Fernandez, 2009).

Questions maybe posed as to: who are women entrepreneurs? What is their role within the tourism and hospitality industry? A woman entrepreneur, as described by Iyiola and Azuh (2014), is a female who indulges and adjusts herself within the financial, socio-economic, and support spheres in society. The characteristics of women entrepreneurs are that they establish their own business, operate, manage and take risks in their businesses (Thuaiba, Azlah, Rozeyta, Hisyamuddin \& Noorizwan, 2007). These types of women entrepreneurs are engaging in the tourism and hospitality industry; although they encounter various challenges, they remain committed towards attaining a livelihood. This paper, therefore, questions the sustainability of women entrepreneurs in the tourism and hospitality industry in South Africa. The paper explores more the challenges and alternative strategies that can assist women to expand their tourism activities for sustainable development and, in the process, reducing poverty and inequalities in communities 
(ILO, 2007). More importantly, the paper aims to contribute positively to the body of knowledge and improve the understanding of how women entrepreneurship, as alluded in the previous section, can improve job creation through the tourism and hospitality industry.

\section{Literature review}

Global context on women entrepreneurship in tourism \& hospitality: Rogerson (2005) asserts that, many international scholars have recognized the need to promote small tourism and hospitality firms which form an integral part of the country's economy (Thomas, 2004). Small tourism firms have been widely criticized by scholars although arguments from Burrows and Curran (1989) expose some critical methodological challenges which are often neglected in literature. Thomas (2004) observes significant differences between small and large tourism enterprise; however, he recognizes important small tourism as fundamental to economic growth and job creation. Several tourism scholars internationally began to embrace small tourism in the 1990s, with women entrepreneurship in tourism sector gaining momentum. According to Thabethe (2006), small tourism firms are driving job creation and improve the economies of developing countries although very few cases have been documented by scholars. Studies (Buhalis \& Cooper, 1998; Wanhill, 2004; Telisman-Kosuta \& Ivandic, 2004) describe small scale tourism as innovative entrepreneurship which is rampant in some rural areas of New Zealand. The contribution of small tourist firms to regional and international development is recognized by international scholars (Pechlaner \& Tschurtschenthaler, 2003; Bastakaiset al, 2004; Erkkila, 2004). Women entrepreneurship, as a form of small tourism in literature, has seen the accommodation sector gaining attention and concern as a viable tourism tool for job creation (Thomas, 2004). Webster (1998) states that, bed and breakfasts in family or holiday cottages on farms or seaside represent an example of small businesses which fall into the category of women entrepreneurship. A distinct comparison of tourism entrepreneurship in developing and developed countries is manifested in studies by Atelejevic and Doorne (2004) and Hall and Rusher (2004). Women entrepreneurship in the tourism sector has encountered stiff challenges as scholars believe it has small profit margins as a small business. This paper, therefore, projects women entrepreneurship as a viable and income generating business given the flourishing tourism and hospitality industry in South Africa.

Policy Context supporting women entrepreneurs in Tourism \& Hospitality Industry: The Constitution of South Africa (1996) in Section 9 of the Bill of Rights disregards any form of discrimination or abuse of any persons despite ethnicity, religion, culture or birth. This statement comes at a time when many women entrepreneurs find it difficult to access government buildings in search of either information or financial help to boost their tourism activities. The Universal Accessibility in Tourism was developed as a counter-measure to leverage women entrepreneurs in participating in the tourism and hospitality industry. In essence, the Universal Accessibility Declaration was an official agreement by stakeholders at a Consultative meeting to ensure freedom of people and empower tourism practitioners to have access to infrastructure, products and series, master plans as well as programs and policies. The Universal Accessibility in Tourism also supports Article 2.2 of the United Nations World Tourism Organizations' (UNWTO) Global Code of Ethics for Tourism, that stipulates "Tourism activities should respect the equality of men and women, they should promote human rights and, more particularly, the individual rights of the most vulnerable groups, notably children, the elderly, the handicapped, ethnic minorities and indigenous people". In an effort to promote women entrepreneurship, the South African Tourism (SAT) was established to encourage persons to travel within the Republic on tourisms activities. The policy ensures that services rendered and facilities made available to tourists portray the highest standards in accordance with the Tourist Act, 1993 (Act No. 72 of 1993). Based on the above assertion, women entrepreneurship in South Africa has been given a leeway to venture into the tourism and hospitality industry as a way of self-creating employment and improving living standards.

Challenges facing women entrepreneurs in Tourism \& Hospitality Industry: The success of women entrepreneurship in the vast tourism and hospitality industry in South Africa is hinged on the national participation of women and willingness to become entrepreneurs. Studies of Gatewood et al. (2003) and Hakala (2008) categorize challenges of women entrepreneurs venturing tourism and hospitality industry. These are:

- human capital;

- strategic choice; and 
- Structural obstacles.

These challenges are constraining the participation of women entrepreneurs in the tourism and hospitality industry, which can lead to increased unemployment. Studies by Hunter and Kapp (2008) and ILO (2012) revealed that such challenges vary by gender, sector, and type of entrepreneurs or region. In the South African context, Hakala (2008) observes that, women entrepreneurs lack technical expertise required and knowledge to confidently make sound decisions to direct their entrepreneurial business. The tourism and hospitality industry needs huge cash injections to be viable; however, women entrepreneurs in South Africa are limited by the lack of financial boost, either from government or stakeholders, which makes women entrepreneurship less lucrative (Worrall, Harris, Thomas, Stewart, Jessop \& Platten, 2008).

Human Capital Theory: A brainchild of Gary Backer, the Human Capital Theory (HCT) became popular since early 1990s. Mincer (1962) cited in Muda and Rafiki (2014: 4) defines the theory of human capital as "education and schooling that will prepare the workforce" whereas Becker (1993) defined it as "a form of investment by individuals in education up to the point where the returns in extra income are equal to the costs of participating in education. Dreher (2003) affirms that, the HCT assumes corporations to be investing less in women's education and training, which is an impediment to women empowerment in organizations. Women entrepreneurship in tourism and hospitality industry in South Africa is suffering a similar fate. The HCT assumes that firms gain competitive advantage by effectively and creatively using resources (Hoopes, Madsen \& Walker, 2003).

Even though, the untapped potential of women entrepreneurship is evident in the tourism and hospitality industry in South Africa, the HCT contends that the learning capacities of individuals are of comparable value to other resources which are involved in the production of goods and services. Schultz (1993) in Nafukho, Hairston and Brooks (2004:546) argues that when a certain resource is utilized effectively, the results will be profitable for the individual, organization and society at large. If women entrepreneurs are trained and given an equal chance to exhibit their entrepreneurial skills, unemployment can be reduced in South Africa. The HCT, therefore, in this paper has been adopted to explain the gains of education and training as a form of investment in human resources, and the main proposition is that people are considered a form of capital for development (Becker, 1993; Nafukho et al., 2004:548). The HCT, as a resource-based theory, is fundamental for this paper because it helps determine how and what resources women can use to become successful in the tourism and hospitality industry. The theory provides significant inspiration on how to become a successful woman entrepreneur in the presence of key aspects such as training. Todaro (2011:365) endorses further that, the HCT provides an analogy of conventional investments in physical capital since people are considered as capital. Broadly explained, the HCT is an investment in individuals 'training and education, which are core factors in advancing women entrepreneurship in the tourism and hospitality industry in South Africa.

Feminist theories: The paper adopts the feminist theory as one of the suitable approaches to supporting women entrepreneurship in tourism and hospitality industry. Kropf et al. (2003) assert that for women strategies to succeed, their feminine strategies which involve collaboration, diversity strategies and work-life need to be present in contrast to masculine strategies for males. To advance the tourism and hospitality industry, women need to be at the helm of power so that they have equal access to resources to explore and make impact in the sector. Beuchamp and Bowie (2004) argue that feminist theory assumes subordination, inequality and oppression of women as unethical hence women deserve equal legal and political rights, which is in contrary to Utilitarian and Kantian theories that neglect the significance of morals and values. The Feminists theories assume inequalities between women and men in terms of advancement and earnings. Such a difference maybe emanating from cultural beliefs where women are more of house minders, with tough work scheduled for men. The paper therefore, seeks to rewrite this ancient belief and empower women to champion women entrepreneurship in the tourism and hospitality industry (Gale, 1994; Orhan \& Scott, 2001). Such an action can empower women to earn their own income and give them power, thereby closing the gap in the Feminist perspective. This theory is important for this paper because it provides an analytical framework on how to deal with inequalities between men and women -the latter are often inhibited to join entrepreneurship which is viable in the tourism and hospitality industry as envisioned in this paper. Deprivation of women, in terms of education or industry experience, is what the Human Capital Theory 
addresses. Women entrepreneurship training can position women at the forefront of the economic sector in South Africa (Appelbaum, Audet \& Miller, 2003).

\section{Methodology}

This paper set out to unlock the potential of women entrepreneurship in the tourism and hospitality industry in the Eastern Cape Province of South Africa. It interrogates the challenges and opportunities which may exist in advancing women entrepreneurship as a tool for job creation. The paper adopted a qualitative research design based on documentary review approach. The rationale was to obtain in-depth data on how women entrepreneurship has been viable in tapping into the tourism and hospitality industry in South Africa. Leedy and Omrod (2010:94) argue that qualitative research design is essential in answering questions about the complex nature of phenomena, more often with the purpose of describing and understanding the phenomena from the participant point of view. The paper sought to respond to questions such as: What is the role of women entrepreneurship in the tourism and hospitality industry? To what extent has women entrepreneurship contributed to job creation within the tourism and hospitality industry? What are the challenges facing women entrepreneurs in their quest to advance the tourism and hospitality industry? Data collected from documents was analyzed qualitatively using content analysis. Jose and Lee (2007:6) affirm that, content analysis should be used for making inferences by objectively and systematically in identifying specialized characteristics of messages. Hofstee (2006:17) endorses further that, content analysis studies closely examine the content of preserved records which are nearly always written documents even though videos can also be used. In this paper, content analysis was used to discuss the common themes from the thick descriptions of the role of women entrepreneurship in stimulating tourism and hospitality industry.

\section{Results}

Becoming innovators and risk takers among women entrepreneurs: In South Africa, women entrepreneurship is flourishing at a slower pace within the tourism and hospitality industry due to lack of innovativeness and risk-taking among women. When compared to men, many small businesses for women die at their infancy due to poor performance of poor decision-making. The gender gap seems visible within the tourism industry where men are doing well despite the difficulties they may face. A study by the GEM (2010) shows that, women entrepreneurs tend to establish small businesses with the fear of expanding hence their return remains low. In terms of business revenue, women income remains relatively low, and this is a setback in exploring the benefits of the tourism and hospitality sector. Women entrepreneurs often face challenges related to limited funding, heavy family workloads and discrimination. The paper argues that women entrepreneurs need to be innovative and be risk takers, which are key principles in growing their businesses within the tourism and hospitality sector.

Improving education and training among women entrepreneurs: Educating a woman in traditional South African society was regarded as mere waste of resources; hence some critics attribute low levels of education among women entrepreneurs as a result of cultural beliefs. An extensive review of literature explains the low levels of education among women entrepreneurs in the tourism and hospitality industry as a result of limited training. The evidence has shown that, women entrepreneurs venture into the tourism industry without the necessary expertise to make proper managerial decisions which can sustain the business. The lack of career guidance is evident among women entrepreneurs, which is an obstacle to job creation through women entrepreneurship. These results are supported by a study by Davis (2010) which reflects that women entrepreneurs lack career guidance and business development information to improve their businesses. In another study in Tunisia, Drine and Grach (2010) observe that women entrepreneurs are failing to reap benefits of entrepreneurship as they do not see the benefits of entrepreneurship support. In South Africa, a study by Chinomona and Maziriri (2015) revealed that women entrepreneurship education should be fostered among young women in education so that they drive the initiative in the tourism and hospitality industry. Drawing insights from these results, women entrepreneurship should be offered in areas of finance education and training, coaching and mentoring and networking since these aspects are essential in driving women entrepreneurship in the tourism sector. 
Enhancing knowledge on the use of Information Communication Technology: Women entrepreneurs in the South African tourism and hospitality industry face challenges in terms of using ICTs due to lack of technical skills as a result of low education levels. The paper acknowledges that, the vast tourism and hospitality sector requires women entrepreneurs who are able to keep abreast of the trends in the technological and economic environment in order to grow their business. Literature, however, provides quite a different picture when it explains women involvement in the tourism sector as being low due to the abovementioned barriers. A study conducted by Lebakeng (2008) in Lesotho attests to the above findings when it argues that women entrepreneurs do not have equal access to relevant information on how they can exploit modern technology to improve efficient in their business. Given the South African context, scholars pose serious questions as to who is to blame for such a huge technical gap in women entrepreneurship. Many versions are suggested as some critics believe gender disparities emanating from patriarchy are the root causes which restrict women into the home, thereby denying them the chance to become innovators. The paper observes a negative relationship between women entrepreneurship and technology use among women entrepreneurs in the tourism and hospitality industry in South Africa. Based on this information, women entrepreneurs in the tourism sector can thrive when they are educated on how they can grow their business using ICT.

The need to provide adequate human and financial resources: The South African government acknowledges the tourism and hospitality industry as an important sector for job creation and economic development. Despite its attractive nature, women entrepreneurs are still encountering challenges in their attempt to exploit the tourism sector. The majority of black women lack collateral security, which makes their relationship with financial institutions sour since they cannot borrow money to finance their business activities. A study by Monolova et al. (2007) supports these findings when it reveals that, women entrepreneurs do not have adequate financial resources, coupled by limited entrepreneurial competence to cope with the challenges of starting up a business. Several women entrepreneurs are failing to grow their businesses as they remain small, and exist only for consumption rather than recreating more employment for the benefit of communities. A critical analysis on the lack of finance and skills makes women entrepreneurs less productive although there is great potential to be tapped into from the tourism and hospitality sector. The government needs to provide adequate financial support to assist struggling women entrepreneurs to make their businesses look vibrant and sustainable.

The scourge of gender based violence in women entrepreneurship: In as much as women entrepreneurs in South Africa have embarked on the tourism and hospitality industry as a viable job creation tool, genderbased violence stands as a hindrance. Documentary review has shown that women in the tourism sector are often harassed, raped, killed and abused by male counterparts, with most cases being under-reported. The protection of women entrepreneurs in the hospitality interest is at risk since the law seems to be relaxed towards such atrocities. Studies (Chu et al., 2008; Reeves, 2010) revealed that women entrepreneurs in the tourism sector are living in fear as threats are often present, which makes women fail to choose the location and time to conduct business. These studies revealed further that the scourge of gender-based violence in South Africa is escalating, thus discouraging women from becoming entrepreneurs and creating their own jobs to sustain their livelihoods. Presently, very few studies have been conducted to document gender based violence in the tourism and hospitality industries although media reports seem to substantiate this gap. These findings reflect the reduced numbers of women entrepreneurs who can become employers and tap the rich tourism and hospitality sector. It remains a challenge to the government to formulate policies that protect the rights of women in entrepreneurship and trade.

\section{Conclusion and Recommendations}

The paper has observes that women entrepreneurship in the tourism and hospitality industry in the Eastern Cape Province in South Africa can be another viable mechanism for accelerating economic growth and curbing unemployment. The extensive documentary review approach has pointed out that skills shortage has affected many sectors of the economy, not only in the Eastern Cape but in South Africa as a whole. Women entrepreneurship (for instance accommodation - bed and breakfast, lodges and small restaurants) can be used to create employment. However, literature had shown that such entrepreneurial ventures need vast amounts of capital, which women lack. The paper opines that many women do not have enough knowledge 
on entrepreneurship in the tourism and hospitality industry. Such contradictions area barrier which the government needs to address through relevant departments such as Small and Medium Business Ministry. The lack of technical know-how is another challenge which inhibits women entrepreneurs from unlocking the potential of tourism and hospitality industry. Modern technology ushered in by globalization and the Fourth Industrial Revolution need to be efficiently utilized to realize economic and social benefits of tourism. The paper challenges women in the Eastern Cape Province to become innovators and seek financial help from monetary institutions to stimulate their entrepreneurial businesses. There is need for government to establish vocational schools that cater for women entrepreneurs so that their knowledge concerning tourism and hospitality is broadened. Networking of women with other tourist agencies (local or international) is fundamental for sharing information on the dynamic tourism sector. A shift in mindset is required among women entrepreneurs in South Africa. A clear diversion from patriarchal beliefs that restrict women to work needs to be done away with. Women need to tap the potential of the tourism and hospitality sector to become employers rather than employees. In terms of policy frameworks, the South African government needs to promulgate more laws that promote women entrepreneurship in tourism, which is a step in reducing employment.

\section{References}

Appelbaum, S. H., Audet, L. \& Miller, J. C. (2003). Gender and leadership? Leadership and gender? A journey through the landscape of theories. Leadership and Organization Development Journal, 24(1/2), 43-52.

Atelejevic, I. \& Doorne, S. (2004). Cultural circuits of tourism: commodities, place and reconsumption, in A.A. Lew, C.M. Hall and A.M. Williams (Eds), A Companion to Tourism, Blackwell, Oxford, 291-302.

Bastakais, C., Buhalis, D. \& Butler, R. (2004). The perception of small and medium-sized tourism accommodation providers on the impacts of the tour operators' power in Eastern Mediterranean. Tourism Management, 25, 151-170.

Beauchamp, T. L. \& Bowie, N. E. (2004). Ethical Theory and Business. 7th Ed. Upper Saddle River, NJ: Pearson/Prentice Hall.

Becker, G. S. (1993). 'Nobel lecture: the economic way of looking at behaviour'. Journal of Political Economy, 101(3), $385-409$.

Buhalis, D. \& Cooper, C. (1998). Competition or co-operation? Small and medium-sized tourism enterprises at the destination, in E.Laws, B. Faulkner and G. Moscardo (Eds), Embracing and Managing Change in Tourism: International Case Studies, Routledge, London, 324-346.

Burrows R. \& Curran J. (1989). Sociological research on service sector small businesses: some conceptual considerations. Work, Employment and Society, 3, 527-539.

Chinomona, E. \& Maziriri, E. T. (2015). Women in Action: Challenges Facing Women Entrepreneurs in the Gauteng Province of South Africa. International Business \& Economics Research Journal, 14(6), 835846.

Chu, H. M., Kara, O. \& Benzing, C. (2008). An Empirical Study of Nigerian Entrepreneurs: Success, Motivations, Problems and Stress. International Journal of Business Research, 8(2), 102-116.

Davis, P. J. (2012). The global training deficit: the scarcity of formal and informal professional development opportunities for women entrepreneurs. Industrial and Commercial Training, 44(1), $19-25$.

Dreher, G. F. (2003). Breaking the glass ceiling: The effects of sex ratios and work-life programs on female leadership at the top. Human Relations, 56(5), 541.

Drine, I. \& Grach, M. (2010). Supporting Women entrepreneurs in Tunisia. September 2010, UN-WIDER working paper. World Institute for Development.

Erkkila, D. (2004). SMEs in regional development, in P. Keller and T. Bieger (eds), The Future of Small and Medium Sized Enterprises in Tourism. International Association of Scientific Experts in Tourism, Publication, 46, 23-34.

Gale, A. (1994). Women in non-traditional occupations: The construction industry. Women in Management Review, 9(2), 3-15.

Gatewood, E. G., Carter, N. M., Brush, C. G., Greene, P. G. \& Hart, M. M. (2003). Women Entrepreneurs, Their Ventures, and the Venture Capital Industry: An Annotated Bibliography. Stockholm: Entrepreneurship and Small Business Research Institute.

Hakala, S. R. (2008). Women entrepreneurs: Challenges and successes in non-traditional industries. PhD Dissertation. University of Phoenix. 
Hall, C. M. \& Rusher K. (2004). Risky lifestyles?: entrepreneurial characteristics of the New Zealand bed and breakfast sector, in R. Thomas (ed), Small Firms in Tourism: International Perspectives. Elsevier, Amsterdam, 83-98.

Hofstee, E. (2006). Constructing a Good Dissertation: A practical Guide to Finishing a Masters, MBA or PHD on schedule. Sandton: EPE.

Hoopes, D. G., Madsen, T. L. \& Walker, G. (2003). Guest editors' introduction to the special issue: Why is there a resource-based view? Toward a theory of competitive heterogeneity. Strategic Management Journal, 24(10), 889-902.

Hunter, S. A. \& Kapp, J. M. (2008). Women Entrepreneurs across Racial Lines: Issues of Human Capital, Financial Capital and Network Structures. Cheltenham, UK: Edward Elgar Publishing.

International Fund for Agricultural Development (IFAD). (2005). From Micro to Small Business: Meeting the growth challenges faced by rural women by H. Perrett. International Labour Organisation.

International Labour Organisation (ILO). (2001). Mayoux L. Jobs, gender and small enterprises: getting the policy environment right. SEED Working Paper No. 15. Geneva.

International Labour Organisation (ILO). (2012). Women's Entrepreneurship Development. Encouraging women entrepreneurs for jobs and development. http. Accessed 24-04-2017.

Iyiola, O. \& Azuh, D. (2014). Women entrepreneurs as small medium enterprise (SME) operators and their roles in socio-economic development in Ota, Nigeria. International Journal of Economics, Business and Finance, 2(1), 1-10.

Jose, A. \& Lee, S. M. (2007). Environmental Reporting of Global Corporations: A Content Analysis Based on Website Disclosure. Journal of Business Ethics, 72, 307-321.

Kropf, M. B., Moore, M., Galinsky, E., Salmond, K., Bond, J. T. \& Harrington, B. (2003). Leaders in a Global Economy: Study of Executive Women and Men. Executive summary. Available at: www.catalystwomen.org [Accessed on 20 April 2017].

Lebakeng, M. A. (2008). An Exploration of Women Entrepreneurship in Lesotho. South Africa. North West University (Master Dissertation).

Leedy, P. D. \& Ormrod, J. E. (2010). Practical research: Planning and design. International and 9th edition. Boston: Pearson.

Nafukho, F. M., Hairston N. R. \& Brooks, K. (2004). Human capital theory: implications for human resource development. Human Resource Development International, 7(4), 545-551.

Manolova, T. S., Carter, M. N., Maney, I. M. \& Cryoshev, B. S. (2007).The differential effect on men and women entrepreneur's human capital and networking on growth expectancies in Bulgaria. Entrepreneurship: Theory and Practice, 31(3), 407-426.

Muda, I. \& Rafiki, A. (2014). Human Resources Development and Performance of Government Provincial Employees: A Study in North Sumatera, Indonesia. Journal of Economics and Behavioral Studies, 6 (2), 152-162.

Pechlaner, H. \& Tschurtschenthaler, P. (2003). Tourism policy, tourism organisations, and change management in Alpine regions and destinations. A European perspective, Current Issues in Tourism, 6, 508-539.

Reeves, M. (2010). Women in Business: Theory, case studies and legal challenges. Routledge, London and New York, 2010.

Rogerson, C. M. (2005). Tourism SMMEs in South Africa: A Case for Separate Policy Development? Working Paper 2.TIPS.

Schultz, T. W. (1993). The economic importance of human capital in modernization. Education Economics, $1(1), 13-19$.

South Africa. The Constitution of the Republic of South Africa. (1996). Pretoria: Government Printer.

Thabethe, E. (2006). Gender and women economic empowerment workshop, February. Ministry of Trade and Industry. Orlando-West. South Africa.[Web] http://www.polity.org.za/article.phppa_cd=81530 [date of access:

Telisman-Kosuta, N. \& Ivandic, N. (2004). Strategic partnerships as a key competitive factor for SMEs: case study of Croatia's small family hotels, in P. Keller and T. Bieger (eds), The Future of Small and Medium Sized Enterprises in Tourism, International Association of Scientific Experts in Tourism, Publication 46, St Gallen, 219-233.

Todaro, M. (2011). Development economics. England: Pearson Education Ltd. 
Thomas R. (2004) International perspectives on small firms in tourism: a synthesis, in R. Thomas (ed), Small Firms in Tourism: International Perspectives, Pergamon, Oxford, 1-12.

Thuaibah, A. B., Azlah, M. A., Rozeyta, O., Hishamuddin, M. S. \& Noorizwan, S. (2007). Women's involvement in entrepreneurship in Johor: a study about critical success factors in achievement and failure in handling business, Project report. UniversitiTeknologi Malaysia.

Orhan, M. \& Scott, D. (2001). Why women enter into entrepreneurship: An explanatory model. Women in Management Review, 16(5), 232.

Wanhill, S. (2004). Government assistance for tourism SMEs: from theory to practice, in R. Thomas (ed), Small Firms in Tourism: International Perspectives. Elsevier, Amsterdam, 53-70.

Webster, M. (1998). Strategies for growth, in Thomas R. (ed), The Management of Small Tourism and Hospitality Firms. Cassell, London, 207-218.

White, M. M., Jones, J. M., Riley, K. \& Fernandez, R. (2009). Women, Family and the Rural Economy. England. Fulbright- Hays Group Project Abroad.

Women in Africa Doing Business, (2008). Case studies of women entrepreneurs across Africa who have overcome legal and regulatory obstacles to create new business opportunities.http://www.doingbusiness.org/ /media/FPDKM/Doing\%20Business/Documents/Sp ecial-Reports/Women-in-Africa.pdf. Accessed 19 April 2017.

Worrall, L., Harris, K., Thomas, A., Stewart, R., Jessop, S. \& Platten, A. (2008). Organisational cultures: Retention and progression barriers to women in the UK construction industry. International Journal of Communities, 8(3), 31-40. 